\title{
Fluid Management in Cesarean Section with Spinal Anesthesia: A Retrospective Study
}

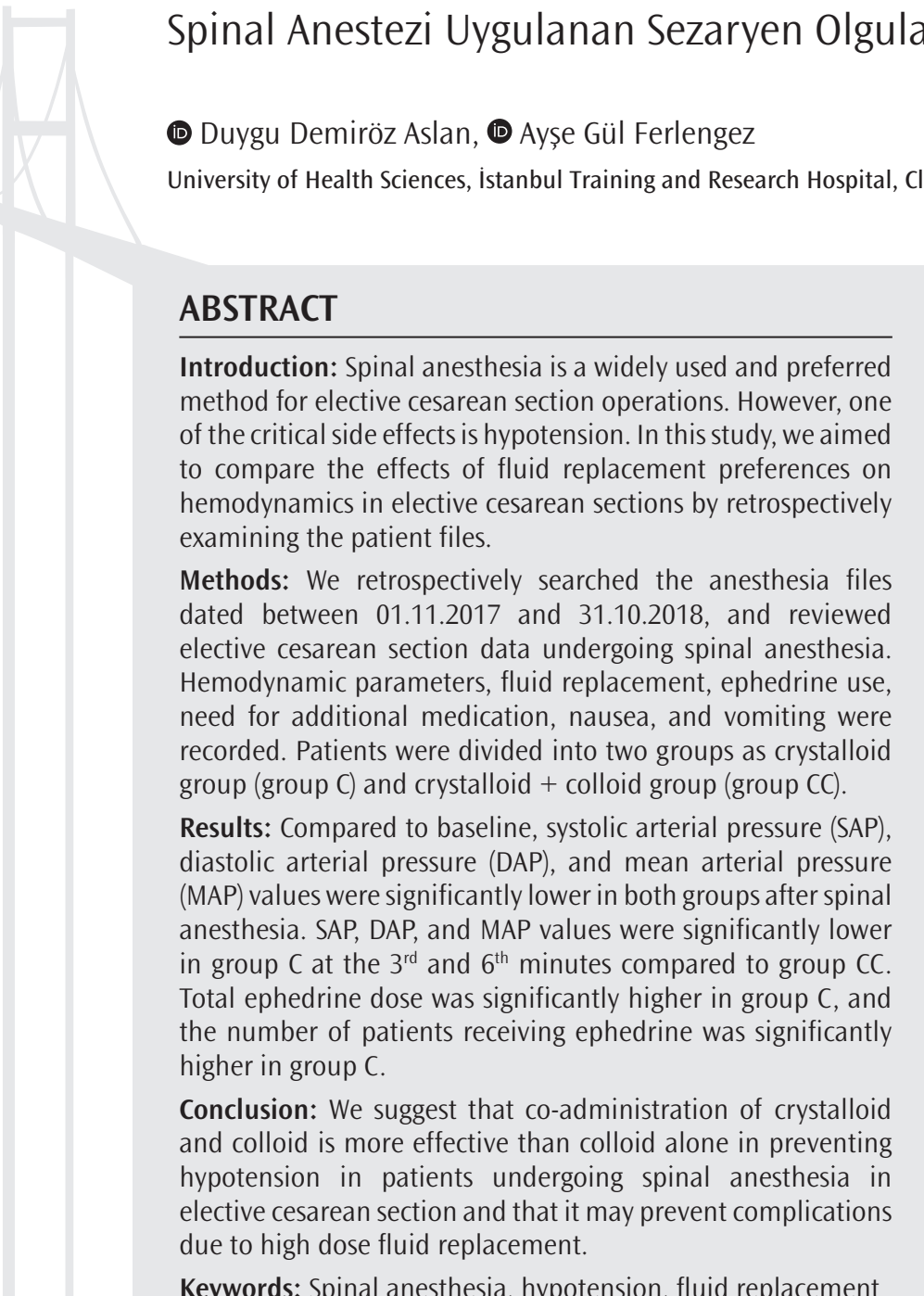

öz

Amaç: Spinal anestezi elektif sezaryen ameliyatları için yaygın kullanılan ve tercih edilen bir yöntemdir. Bununla birlikte önemli yan etkilerinden birisi de hipotansiyondur. Çalıșmamızda elektif sezaryenlerde sıvı replasman tercihlerinin hemodinami üzerine etkisini retrospektif olarak karşılaștırmayı amaçladık.

Yöntemler: Hastanemizde 01.11.2017-31.10.2018 arası aylara ait anestezi dosyaları geriye dönük taranarak spinal anestezi uygulanan elektif sezaryen verileri incelendi. Hastaların hemodinamik parametreleri, SIVı replasmanı, efedrin kullanımı, ek ilaç intiyacı, bulantı ve kusma olup olmadığı kaydedildi. Sadece kristalloid verilenler grup K, kristalloid ve kolloid birlikte verilenler grup KK olarak adlandırıldı.

Bulgular: Her iki grupta da spinal anestezi uygulaması sonrası sistolik arteriyal basınç (SAB), diastolik arteriyal basınç (DAB), ortalama arteriyal basınç $(\mathrm{OAB})$ ölçümleri giriş değerlere göre anlamlı olarak düşük bulundu. grup K'de 3. ve 6. dakika SAB, $D A B, O A B$ değerleri grup KK'ye göre anlamlı olarak düşük saptandı. Efedrin kullanılan hasta sayısı ve kullanılan toplam efedrin dozu grup K'de anlamlı olarak yüksek bulundu.

Sonuç: Elektif sezaryenlerde spinal anestezi uygulanacak hastalarda hipotansiyonun önlenmesinde kristalloid ve kolloidin birlikte uygulanmasının sadece kolloid uygulanmasına göre daha etkili olup yüksek doz sıvı replasmanına bağlı komplikasyonları da önleyebileceğini düşünmekteyiz.

Anahtar Kelimeler: Spinal anestezi, hipotansiyon, SIVI replasmanı

\section{Introduction}

Numerous maternal deaths have been reported due to complications of general anesthesia, including oxygenation insufficiency and aspirationrelated complications caused by complicated and unsuccessful tracheal intubations, and regional anesthesia has been preferred for these reasons (1-3). Spinal anesthesia is widely used for emergency and elective cesarean section operations due to the rapid onset of action and adequate anesthesia. However, the most common side effect is hypotension, and the incidence can be reduced by up to $40 \%$ despite treatments and applications to prevent it. Pregnant women at term are more prone to spinal anesthesia-related hypotension, and this is due to aortocaval compression, uterine contractions, engagement of the fetal 
head, and rapid development of sympathetic blockade. Supine position, hypovolemia, spinal, and epidural block increase the incidence and severity of aortocaval compression $(4,5)$.

Crystalloid infusion before spinal anesthesia is a common method to prevent hypotension; however, this does not always prevent hypotension. It is known that the clinical and intraoperative use of colloid solutions is highly effective on hypotension (6).

In this study, elective cesarean sections performed in our hospital in 2018 were retrospectively reviewed. We aimed to compare hypotension and other hemodynamic parameters of patients who received crystalloid infusion alone and who received crystalloid + colloid infusion.

\section{Methods}

\section{Patient Selection}

Following University of Health Sciences, İstanbul Training and Research Hospital Ethics Committee (decision no: 1505, date: 09.11.2018), the files of the patients who underwent elective cesarean section under spinal anesthesia between 01.11.2017 and 31.10.2018 were retrieved from Hospital Information Management Systems and examined retrospectively. The necessary consent for interventions, treatments, and using the data are included in the patient files. Since it was a retrospective study, consent was not obtained from the patients. The data of patients who were given preoperative $10 \mathrm{~mL} / \mathrm{kg}$ crystalloid infusion (group C) and preoperative $5 \mathrm{~mL} / \mathrm{kg}$ crystalloid $+5 \mathrm{~mL} / \mathrm{kg}$ colloid infusion (group CC) were recorded. We examined the anesthesia files of the patients and compared the effect of preoperative fluid type between the two groups on hypotension and other hemodynamic parameters.

In our clinic, preoperative fluid replacement is performed by anesthesiologists to prevent maternal hypotension. One group of anesthetists routinely used $10 \mathrm{~mL} / \mathrm{kg}$ crystalloid 15-20 minutes before spinal anesthesia for fluid replacement to prevent maternal hypotension, while the other group used $5 \mathrm{~mL} / \mathrm{kg}$ crystalloid $+5 \mathrm{~mL} /$ $\mathrm{kg}$ colloid infusion.

Hypotension was considered as a 30\% decrease from baseline mean arterial pressure (MAP), and bradycardia was accepted when the heart rate (HR) was below 50 beats/min. Intravenous bolus ephedrine was administered in hypotension, and atropine was administered in bradycardia. Spinal anesthesia was performed with a 26 gauge quincketipped spinal needle in the sitting position from the L3-4 or L4-5 interval, and the dose of heavy bupivacaine used was administered according to the patient's height. The amount of drug used in spinal anesthesia, the level of intervention, the diameter and type of the needle used were retrospectively analyzed and recorded from the anesthesia file.
The files were examined retrospectively for age, height, weight, American Society of Anesthesiologists (ASA) physical status classification system category, total ephedrine used, time of ephedrine use, further drug use, presence of nausea and vomiting, and bleeding. Systolic arterial pressure (SAP), diastolic arterial pressure (DAP), MAP, HR, and saturation values $\left(\mathrm{SPO}_{2}\right)$ were measured at baseline, after intrathecal drug administration and at $3^{\text {rd }}, 6^{\text {th }}, 9^{\text {th }}, 12^{\text {th }}, 15^{\text {th }}$ minutes during surgery.

\section{Statistical Analysis}

SPSS 16.0 statistical package program was used for statistical analysis of the data. Descriptive statistics of numerical variables were expressed as mean \pm standard deviation, while categorical variables were expressed as frequency (n) and percentage (\%). Kolmogorov-Smirnov or ShapiroWilk tests were used to determine whether the data fit the normal distribution. Pearson chi-square test or Fisher's exact chi-square test was used for the analysis of categorical data. A paired t-test or Wilcoxon test was used for the analysis of continuous variables. The level of significance was set at $p<0.05$.

\section{Results}

In this study, 186 patient files were examined. Thirty-six patients were excluded due to lack of data, severe systemic disease, multiple pregnancies, morbid obesity, height below $150 \mathrm{~cm}$, and being under 18 years of age. There were 65 patients in group $C$ and 85 patients in group CC.

Age, weight, height, and ASA scores of the patients were similar in both groups, and there was no statistically significant difference. The mean age of the patients was $29.6 \pm 6$ years in group $C$ and $28.7 \pm 7$ years in group CC. The mean height of the patients was $161 \pm 2 \mathrm{~cm}$ in group C and $162 \pm 4 \mathrm{~cm}$ in group CC. The mean weight of the patients was $63 \pm 8$ $\mathrm{kg}$ in group $\mathrm{C}$ and $62 \pm 9 \mathrm{~kg}$ in group CC. In group C, there were 45 ASA 1 patients and 20 ASA 2 patients. In group CC, there were 51 ASA 1 patients and 34 ASA 2 patients.

In both groups, baseline SAP, DAP, and MAP values were significantly higher than those measured after spinal anesthesia (Table 1). SAP, DAP, and MAP values at $3^{\text {rd }}$ and $6^{\text {th }}$ minutes were significantly lower in group $C$ than in group CC (Table 2).

The number of patients receiving ephedrine was 43 (66.2\%) in group C, and this was significantly higher than 25 patients (29.4\%) receiving ephedrine in group CC. Total ephedrine dose was significantly higher in group C than in group CC (7.0 $\pm 6.6 \mathrm{mg}$ vs $3.2 \pm 5.8 \mathrm{mg}$ ) (Table 3 ).
Table 1. Measured SAP, DAP and MAP values of the groups

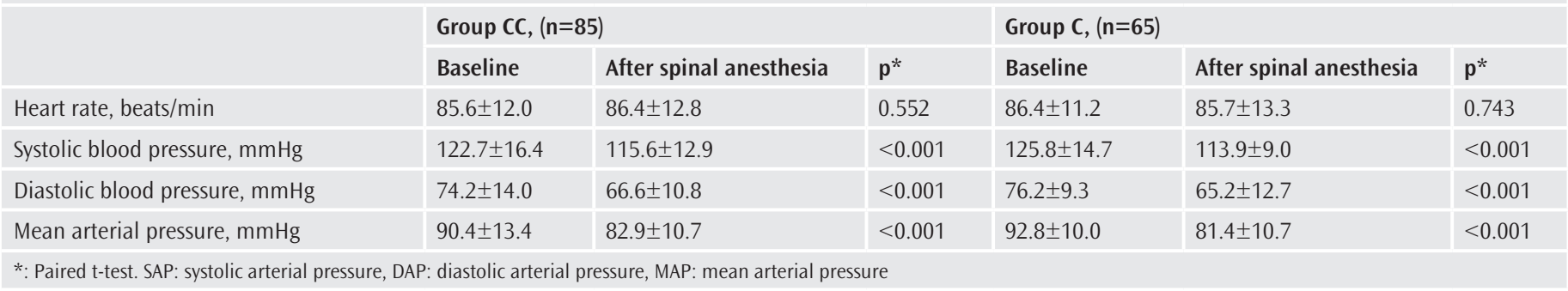


Atropine requirement was not detected in both groups. In both groups, no additional medication was required. Nausea rates were similar in both groups. The mean bleeding was similar in both groups, and there were no additional complications.

\section{Discussion}

Patients undergoing cesarean section have potential risks related to anesthesia as well as complications of surgical operation. Regional anesthesia has been preferred in recent years because of its advantages such as the patient being conscious, lack of aspiration risk, and not causing respiratory depression in the newborn (3).

In addition to the advantages of spinal anesthesia in cesarean section, maternal hypotension due to sympathetic blockade is the most common and undesirable effect of spinal anesthesia, and severe hypotension may cause fetal acidosis and neonatal depression by decreasing uterine and intervillous blood flow. It may cause maternal nausea and vomiting (7).

Although the validity of pre-loading with crystalloid and colloid solutions before spinal anesthesia is discussed today, it is still the most commonly used method to prevent hypotension $(8,9)$. It was emphasized that hypotension would be prevented by increasing the intravascular volume by giving $10-15 \mathrm{~mL} / \mathrm{kg}$ crystalloid solution in a short time before spinal intervention (10). However, other studies have shown that intravascular crystalloid application does not have a sufficient effect on the incidence of hypotension due to spinal anesthesia (11). In recent years, Jackson et al. (12) have suggested that $1000 \mathrm{~mL}$ crystalloid infusion has no difference in preventing hypotension after cesarean section in comparison to $200 \mathrm{~mL}$ and that pre-hydration should be abandoned. Park et al. (13) reported that loading the patients with a volume higher than $10 \mathrm{~mL} / \mathrm{kg}$ before cesarean delivery did not provide an advantage. In another study, it was emphasized that hydration with crystalloid given before spinal anesthesia caused more pronounced hypotension than hydration after spinal block (14). In a study performed with colloids to prevent hypotension due to spinal anesthesia in cesarean operations, it was emphasized that intravascular administration of $5 \%$ albumin was effective, but albumin solutions were expensive, and that gelatin and starch solutions were as effective as $5 \%$ albumin in expanding intravascular volume with less cost $(12,15)$.

Studies have shown that colloids remain in the vascular area for a longer period by showing the superiority of colloids over crystalloid in preventing post-spinal hypotension in elective cesarean operations $(6,11)$. Ueyama et al. (16) similarly showed that only $28 \%$ of the lactated ringer solution administered at $30^{\text {th }}$ minutes remained in the intravascular area, while this rate was $100 \%$ with the HES solution. However, in recent years, some studies have shown that colloid pre-hydration, as well as crystalloid, is inadequate in reducing hypotension due to spinal anesthesia. Buggy et al. (17) concluded that although $500 \mathrm{~mL}$ colloid pre-hydration kept SAP levels higher, it did not reduce the incidence of hypotension and ephedrine use when compared to groups with or without crystalloid pre-hydration. In the study of Baraka et al. (11), $7 \mathrm{~mL} / \mathrm{kg}$ intravascular administration of $3 \%$ gelatin in electrolyte solution led to a significant increase in central venous pressure and showed less hypotension after spinal anesthesia compared with intravascular administration of equal volume of isotonic sodium chloride. In their study, Idehen et al. (18) compared the incidence of hypotension in cases of cesarean section and found that hydration with crystalloid/colloid fluid combination for 15 minutes showed better efficacy in the prophylaxis of hypotension compared with colloid.

In a meta-analysis by Ripollés et al. (19) including 11 randomized clinical trials and 990 patients, they reported that the use of colloids provided a significant reduction in the incidence of spinal anesthesia-induced hypotension compared to crystalloid. Similar to other studies, BP levels were found to be significantly lower in patients treated with crystalloid infusion compared to the group treated with colloidal plus crystalloid hydration in our study.

Administration of high doses of crystalloid leads to peripheral and pulmonary edema (20). Crystalloids are thought not to have sufficient

\section{Table 2. SAP, DAP and MAP values of the groups measured at 3 and 6 minutes after spinal anesthesia}

\begin{tabular}{|c|c|c|c|}
\hline & Group CC, $(n=85)$ & Group $C,(n=65)$ & $p^{*}$ \\
\hline 3. min. Heart rate, beats/min & $80.2 \pm 10.2$ & $82.2 \pm 13.6$ & 0.324 \\
\hline 3. min. Systolic blood pressure, $\mathrm{mmHg}$ & $102.2 \pm 9.5$ & $96.1 \pm 16.1$ & 0.007 \\
\hline 3. min. Diastolic blood pressure, $\mathrm{mmHg}$ & $64.9 \pm 10.9$ & $59.7 \pm 10.5$ & 0.004 \\
\hline 3. min. Mean arterial pressure, $\mathrm{mmHg}$ & $77.3 \pm 9.2$ & $71.8 \pm 10.5$ & 0.001 \\
\hline 6. $\mathrm{min}$. Heart rate, beats/min & $83.4 \pm 11.2$ & $82.0 \pm 9.1$ & 0.417 \\
\hline 6. min. Systolic blood pressure, $\mathrm{mmHg}$ & $99.4 \pm 10.3$ & $96.1 \pm 13.2$ & 0.094 \\
\hline 6. min. Diastolic blood pressure, $\mathrm{mmHg}$ & $66.9 \pm 12.1$ & $61.6 \pm 12.3$ & 0.009 \\
\hline 6. min. Mean arterial pressure, $\mathrm{mmHg}$ & $77.7 \pm 9.6$ & $73.1 \pm 11.7$ & 0.009 \\
\hline
\end{tabular}

Table 3. Number of patients receiving ephedrine and dose of ephedrine

\begin{tabular}{|l|l|l|}
\hline & Group CC, (n=85) & Group C, (n=65) \\
\hline Number of patients receiving ephedrine (\%) & $25(29.4 \%)$ & $43(66.2 \%)$ \\
\hline Total dose of ephedrine, mg & $3.2 \pm 5.8$ & $7.0 \pm 6.6$ \\
\hline *: chi-square test, \#: t-test & & $<0.001^{*}$ \\
\hline
\end{tabular}


effect on its own due to the rapid redistribution to the intravascular compartment. A high amount of crystalloid infusion may cause pulmonary edema by disrupting oxygen transport in the blood. It is stated that excessive fluid replacement will increase extravasation by diluting plasma proteins (13). In our study, total crystalloid infusion dose was not over $10 \mathrm{~mL} / \mathrm{kg}$ in both groups, and no additional complications were detected.

In addition to the advantages of colloids, there are disadvantages of pre-loading with colloids such as higher cost, hemodilution effect, fluid overload, and anaphylactoid reaction risk (21). Also, it is known that colloids administered at high doses have adverse effects on the coagulation profile (22). In our study, the amount of bleeding was similar to the crystalloid group in patients treated with colloid plus crystalloid, and we think that this result is due to low dose colloid administration. Also, anaphylaxis and similar reactions were not observed in both groups.

\section{Conclusion}

In this study, we think that the co-administration of crystalloid and colloid is more effective in preventing hypotension due to spinal anesthesia in cesarean operations than colloid alone. We also think that the use of crystalloid and colloids together is more effective in avoiding the side effects of high dosing of crystalloid or colloid infusions in preoperative fluid selection.

Ethics Committee Approval: Following University of Health Sciences, İstanbul Training and Research Hospital Ethics Committee (decision no: 1505 , date: 09.11 .2018 ), the files of the patients who underwent elective cesarean section under spinal anesthesia between 01.11.2017 and 31.10.2018 were retrieved from Hospital Information Management Systems and examined retrospectively.

Informed Consent: Since it was a retrospective study, consent was not obtained from the patients.

Peer-review: Externally peer-reviewed.

Author Contributions: Surgical and Medical Practices - D.D.A., A.G.F.; Concept - D.D.A., A.G.F.; Design - D.D.A., A.G.F.; Data Collection and/or Processing - D.D.A., A.G.F.; Analysis and/or Interpretation - D.D.A., A.G.F.; Literature Search - D.D.A., A.G.F.; Writing Manuscript - D.D.A., A.G.F.

Conflict of Interest: No conflict of interest was declared by the authors.

Financial Disclosure: The authors declared that this study received no financial support.

\section{References}

1. Göktuğ A, Özayar E, Oba ș, Uysalel A. Sezaryen olgularında uygulanan rejyonel anestezi tekniklerinin yan etkilerinin sonuçları. Türk Anest Rean Der 2007; 35: 145-51.

2. Günüsen I, Karaman S, Akercan F, Fırat V. Elektif sezaryenlerde farklı anestezi yöntemlerinin yenidoğan üzerine etkileri: Retrospektif çalışma. Ege Tıp Dergisi 2009; 48: 189-94.

3. McDonnell NJ, Paech MJ. General anaesthesia for emergency caesarean delivery: is the time saved worth the potential risks? Aust NZJ Obstet Gynaecol 2012; 52: 311-22.
4. Warwick D, Ngan K. Managing hypotension during anesthesia for caesarean section. Anaesth Intensive Care 2007; 8: 286-9.

5. Juhani TP, Hannele H. Complications during spinal anesthesia for caserean delivery: A clinical report of one year's experience. Reg Anesth 1993; 18: 12831.

6. Morgan. GE JR. Clinical anesthesiology, third edition. Appleton Lange 2002: 626-43.

7. Esener Z. Klinik anestezi. İstanbul: Logos yayımcılık 1991: 363-428.

8. Okutan M, Kocamanoğlu S, Ener B, Karakaya D, Sarlhan B, Tür A. Sezaryen cerrahisi için uygulanan spinal anesteziyle ilişkili hipotansiyonun önlenmesi. TARD Dergisi 2006; 34: 27-34.

9. Critchley LA. Hypotension, subarachnoid block and the elderly patient. Anaesthesia 1996; 51: 1139-43.

10. Lee JA, Atkinson RS, Watt JW. Lumbar puncture and spinal anesthesia. 4th ed. Edinburg: Churchill Livingstone 1985: 106-20

11. Baraka AS, Taha SK, Ghabach MB, Sibaii AA, Nader AM. Intravascular administration of polymerized gelatin versus isotonic for prevention of spinalinduced hypotension. Anesth Analg 1994; 78: 301-5.

12. Jackson R, Reid JA, Thorburn J. Volume preloading is not essential to the preventin of spinal-induced hypotension at caesarean sction. Br J Anaesth 1995; 75: 262-5.

13. Park GE, Hauch MA, Curlin F, Datta S, Bader AM. The effects of varying volumes of cyristalloid administration before cesarean delivery on maternal hemodynamics and colloid osmotic pressure. Anesth Analg 1996; 83: 299-303.

14. Ni HF, Liu HY, Zhang J, Peng K, Ji FH. Crystalloid coload reduced the incidence of hypotension in spinal anesthesia for cesarean delivery, when compared to crystalloid preload: A meta-analysis. Biomed Res Int 2017; 2017: 3462529.

15. Mathru M, Rao TLK, Kartha RL, Shanmugham M, Jacobs HK. Intravenous albumin administration for prevention of spinal hypotension during Cesarean section. Anesth Analg 1980; 59: 655-8.s

16. Ueyama H, Le H, Tanigami H, Mashimo T, Yoshiya I. Effects of crystalloid and colloid preload on blood volume in the parturient undergoing spinal anesthesia for elective cesarean sectin. Anesthesiology 1999; 91: 1571-6.

17. Buggy D, Higgins P, Moran C, O'Brien D, O'Donovan F, McCarroll M. Prevention of spinal anesthesia-induced hypotension in the elderly: Comparison between preanesthetic administration of crystalloids, colloids and no prehidration. Anesth Analg 1997; 84: 106-10.

18. Idehen HO, Amadasu FE, EkwerelT. Comparison of intravenous colloid and colloid-crystalloid combination in hypotensionprophylaxis during spinal anesthesia for cesarean section. Niger J Clin Pract 2014; 17: 309-13.

19. Ripollés Melchor J, Espinosa Á, Martínez Hurtado E, Casans Francés R, Navarro Pérez R, Abad Gurumeta A, et al. Colloids versus crystalloids in the prevention of hypotension induced by spinal anesthesia in elective cesarean section. A systematic review and meta-analysis. Minerva Anestesiol 2015; 81: 1019-30.

20. Sharma SK, Gajraj NM, Sidavi JE. Prevention of hypotension during spinal anesthesia: a comparision of intravascular administration of hetasarch versus lactated Ringer's solution. Anesth Analg 1997; 84: 111-4.

21. Kee WDN, Khaw KS, Lee BB, Ng FF, Wong MM. Randomized controlled study of colloid preload before spinal anaesthesia for Caesarean section. Br J Anaesth 2001; 87: 772-4.

22. Vercauteren MP, Hoffman V, Copejans HC, Van Steenberge AL, Adriaensen HA. Hyrdoxyethylstarch compared with modified gelatin as volume preload before spinal anaesthesia for caesarean section. Br J Anaesth 1996; 76: 731-3. 